\title{
ANALISIS KESALAHAN SHIEKIBUN PADA MAHASISWA PENDIDIKAN BAHASA JEPANG TAHUN MASUK 2017 UNIVERSITAS NEGERI PADANG
}

\author{
Indri Rizka Permata Andra', Hendri Zalman ${ }^{2}$
}

Program Studi Pendidikan Bahasa Jepang ${ }^{1}$ (Jurusan Bahasa dan Sastra Inggris, Fakultas Bahasa dan Seni, Universitas Negeri Padang)

Program Studi Pendidikan Bahasa Jepang ${ }^{2}$ (Jurusan Bahasa dan Sastra Inggris, Fakultas Bahasa dan Seni, Universitas Negeri Padang)

Email Penulis : tiffanifani4@gmail.com

\begin{tabular}{lr}
\hline \multicolumn{3}{l}{ Sejarah Artikel } \\
\hline Submit $\quad: 2020-06-17$ \\
Diterima $:$ :2020-06-18 \\
Diterbitkan : 2020-07-20
\end{tabular}

Kata Kunci:

Error Analysis, shiekiebun

\begin{abstract}
Abstrak
This study discusses the shiekiebun's error analysis of students entering the 2017 Japanese language education study program Padang State University. The purpose of this study was to determine the form of errors, types of errors, and causes of misuse of shiekibun at 2017 students entering the Japanese language study program at Padang State University. This type of research used in this research is qualitative research with descriptive methods. The population in this study is the students entering the 2017 Japanese Language Education Study Program Padang State University, amounting to 56 people. The sample in this study amounted to 30 people. The data of this study are the shiekiebun's test error score for students entering 2017 in the Japanese language study program at Padang State University. Based on the results of research conducted it can be concluded that there is a form of morphological error of $40.2 \%$, and in the form of syntax error of $59.8 \%$. Then there is the type of lapses error of $53.8 \%$, and Mistake of $46.2 \%$. And the causes of errors caused by performance factors are $23.8 \%$, competence factor is $70.7 \%$, and generalization factors are $5.5 \%$.
\end{abstract}

\section{PENDAHULUAN}

Bahasa merupakan alat komunikasi terpenting yang dibutuhkan manusia dalam menjalani aktivitas kehidupan sehari-hari. Bahasa membuat manusia dapat mengutarakan maksud hati dan pikirannya kepada orang lain. Sama dengan manusia yang memilki karakteristik yang berbeda-beda, bahasa juga demikian. Karakteristik bahasa Indonesia akan berbeda dengan karakteristik bahasa manapun di dunia. Jadi, wajar jika karakteristik bahasa Indonesia akan dipandang unik oleh orang Jepang. Sebalikya, karakteristik bahasa Jepang juga sangat unik bagi orang Indonesia.

\footnotetext{
${ }^{1}$ Mahasiswa Prodi Pendidikan Bahasa Jepang FBS UNP Iulus pada Desember 2019

2 Dosen Prodi Pendidikan Bahasa Jepang FBS UNP
} 
Keunikan karakteristik bahasa Jepang dapat dilihat dari huruf, kata, gramatika, dan lain sebagainya. Keunikan tersebut menjadikan bahasa Jepang sulit bagi pembelajar orang Indonesia.

Keunikan bahasa Jepang dari segi huruf dapat dilihat dari bermacam huruf yang digunakan, yaitu: hiragana, katakana, kanji, dan romaji. Dalam menulis sebuah kalimat, penggunaan huruf ini bisa saja dilakukan secara bersamaan. Sangat berbeda dengan bahasa Indonesia yang hanya menggunakan satu jenis huruf, yaitu huruf latin. Perbedaan huruf, ditambah dengan penggunaan huruf Jepang yang bisa berbeda huruf dalam satu kalimat ini tentu menjadi tantangan sekaligus hambatan bagi pembelajar bahasa Jepang penutur Indonesia.

Dari segi kata dan gramatika, bahasa Jepang juga sangat berbeda dengan bahasa Indonesia. Kata di dalam bahasa Jepang ada yang mengalami perubahan bentuk karena proses gramatikal, mengikuti fungsi kalimat yang dibuat. Misalnya, kata kerja (doshi) "taberu" akan berubah menjadi "tabeta" ketika digunakan untuk membentuk kalimat yang mengandung fungsi waktu lampau. Di samping itu, keunikan lainnya dari segi gramatika, pembentukan semua jenis kalimat bahasa Jepang, selalu melibatkan sebuah kelas kata yang tidak bisa berdiri sendiri, yaitu partikel (joshi). Meskipun tidak dapat berdiri sendiri, joshi memiliki fungsi yang sangat penting di dalam kalimat. Joshi menjadi penanda fungsi bagi kata yang diikutinya. Misalnya, joshi "wa” dan " $o$ "pada kalimat berikut ini:

$$
\begin{aligned}
& \text { わたしはごはんをたべます } \\
& \text { watashi wa gohan wo tabemasu. }
\end{aligned}
$$

Saya makan nasi (Mangerongkonda,2013:2)

Joshi "wa" (lihat は) pada kalimat di atas memiliki fungsi sebagai penanda bahwa kata "watashi” (lihat わたし) yang berada sebelumnya adalah subjek kalimat. Sedangkan joshi “o”(lihat ) yang didahuluinya adalah objek dari kalimat di atas. Dari contoh perubahan "taberu" menjadi "tabeta" hingga contoh penggunaan joshi di dalam kalimat di atas, dapat diasumsikan bahwa perubahan kata dan joshi merupakan unsur yang sangat penting sekaligus sulit untuk dikuasai bagi pembelajar bahasa Jepang penutur Indonesia.

Seperti telah dipaparkan di atas, bahwa keunikan gramatika bahasa Jepang yang terlihat dari perubahan bentuk kata dan joshi di atas, disebabkan oleh fungsi dari kalimat bahasa Jepang. Artinya, fungsi kalimat merupakan bagian dari sistem gramatika yang mempengaruhi sehingga sebuah kata berubah bentuk serta sebuah partikel menjadi memiliki fungsi yang jelas. Salah satu fungsi kalimat bahasa Jepang tersebut adalah fungsi kausatif (Shieki).

Dalam buku nihongo no bunpo dijelaskan bahwa shieki merupakan salah satu bentuk kata kerja bermakna menyuruh atau membuat seseorang melakukan aktifitas. Dalam bahasa Inggris disebut dengan istilah Causative Voice, dalam bahasa Indonesia istilah shieki disebut juga sebagai kata kerja bentuk menyuruh

(Sutedi,2007 : 132). Sebagai contoh kalimat 先生は私にほんを読ませる(sensei wa watashi ni hon wo yomaseru) yang berarti "saya disuruh sensei membaca buku". 
Pada kalimat diatas, kata 読ませる (yomasesu) yang berarti (disuruh membaca) berasal dari kata 読む (yomu), huruf む $(m u)$ mengalami perubahan ま (ma) dan dibubuhkan せる (seru)

Berdasarkan contoh kalimat diatas, subjek seperti biasanya diikuti oleh kata bantu $w a / g a$. Kemudian objek diikuti kata bantu $o$ dan orang yang disuruhnya diikuti oleh kata bantu $n i$. Kata bantu $n i$ dalam pola kalimat diartikan menjadi kepada jadi. Seseorang yang menjadi sunjek kalimat tersebut menyuruh melakukan sesuatu pada seseorang yang diikuti oleh kata bantu $n i$. Adapun contoh kesalahan yang dilakukan oleh peneliti terdahulu Mangerongkonda (2013) その仕事、私をやらせてくださ い, pada soal ini pembelajar menjawab (wo) melakukan kesalahan dalam menentukan fungsi partikel pada kata kerja kausatif. Hal ini dikarenakan pembelajar beranggapan bahwa kalimat tersebut di atas menunjukkan objek dari suatu perbuatan. Pembelajar tidak mengetahui bahwa fungsi sebenarnya partikel wo dalam kata kerja kausatif yaitu subjek membuat seseorang melakukan sesuatu atau menyuruh seseorang melakukan sesuatu. Dari hasil wawancara dengan dosen, materi shiekibun tidak ada penilaian khuhus mengenai kemampuan mahasiswa tentang materi shiekibun.

Berdasarkan pemaparan di atas dapat diasumsikan bahwa shiekibun susah untuk dikuasai dan berpotensi membuat pembelajar Indonesia melakukan kesalahan. Untuk mendeskripsikan bentuk, jenis dan penyebab kesalahan shiekibun perlu dilakukan penelitian.

Contoh kesalahan penggunaan shieki doushi yang dibentuk dari kalimat transitif atau intransitif seperti dalam kalimat berikut.

(1) せいとはしゅくだいをします。(Salah)

Seito wa shukudai wo shimasu.

(2) せんせいはせいとにしゅくだいをさせる。( Benar)

Sensei wa seito ni shukudai wo saseru.

(Dalam sudjianto,dahidi:2009)

Kesalahan kalimat pertama tidak ada orang yang menyuruh, cuman disebutkan kalau siswa mengerjakan tugas, tapi kalimat kedua disebutkan siapa yag memberikan perintah yang memberi perintah adalah gurunya, dan kalimat kedua diikuti juga dengan partikel wo.

Adanya kesulitan dalam membuat perubahan shieki doushi menjadi hambatan dalam penggunaan bahasa Jepang dengan baik.

\section{METODE PENELITIAN}

Jenis penelitian ini yaitu penelitian kualitatif. Data dalam penelitian ini adalah nilai tes kesalahan shiekiebun mahasiswa tahun masuk 2017 program studi pendidikan bahasa Jepang Universitas Negeri Padang. Metode penelitian yang digunakan dalam penelitian ini adalah metode deskriptif. Populasi dalam penelitian ini yaitu mahasiswa tahun masuk 2017 Prodi Pendidikan Bahasa Jepang Universitas 
Negeri Padang yang berjumlah 56 orang. Adapun sampel dalam penelitian ini yaitu sebanyak 30 orang.

Tes yang digunakan dalam penelitian ini berupa tes diagnostik. Bentuk tes yang digunakan dalam penelitian ini adalah tipe tulisan berbentuk objektif dan essay. Dalam penelitian ini tes yang diberikan adalah tes pilihan ganda dan essay.

Langkah pertama, mengklasifikasi kesalahan berdasarkan bentuk, Kedua mengklasifikasi kesalahan berdasarkan jenis, Ketiga mengklasifikasi kesalahan berdasarkan penyebab, dan Keempat memasukkan ke table analisis data.

\section{HASIL DAN PEMBAHASAN}

\section{Hasil}

Berdasarkan analisis kesalahan shiekiebun mahasiswa tahun masuk 2017 program studi pendidikan bahasa Jepang Universitas Negeri Padang sebagai berikut.

\section{Bentuk Kesalahan Penggunaan shiekibun}

\begin{tabular}{|l|l|l|}
\hline Bentuk Kesalahan & Jumlah Kesalahan & Persentase \\
\hline Morfologi & 291 & $40,2 \%$ \\
\hline Sintaksis & 432 & $59,8 \%$ \\
\hline Total & 723 & $100 \%$ \\
\hline
\end{tabular}

Jenis Kesalahan Penggunaan shiekibun

\begin{tabular}{|l|l|l|}
\hline Jenis Kesalahan & Jumlah Kesalahan & Persentase \\
\hline Lapses & 389 & $53,8 \%$ \\
\hline Mistake & 334 & $46,2 \%$ \\
\hline Total & 723 & $100 \%$ \\
\hline
\end{tabular}

\section{Penyebab Kesalahan Penggunaan Kalimat Pasif}

\begin{tabular}{|l|l|l|}
\hline Peneybab Kesalahan & Jumlah Kesalahan & Persentase \\
\hline Faktor Performansi & 172 & $23,8 \%$ \\
\hline Faktor Kompetensi & 511 & $70,7 \%$ \\
\hline Faktor Generalisasi & 40 & $5,5 \%$ \\
\hline Total & 723 & $100 \%$ \\
\hline
\end{tabular}


Berdasarkan pada penelitian yang telah dilakukan tentang analisis kesalahan shiekibun pada mahasiswa pendidikan bahasa Jepang tahun masuk 2017 Universitas Negeri Padang, dapat ditarik kesimpulan bahwa ditemukannya bentuk kesalahan (morfologi dan sintaksis), jenis kesalahan (lapses dan mistake) dan penyebab kesalahan ( faktor performansi, faktor kompetensi dan faktor generalisasi) pada shiekibun. Diantara bentuk kesalahan morfologi dan sintaksis, kesalahan yang paling tinggi terjadi adalah bentuk kesalahan sintaksis.

\section{Pembahasan}

Bentuk kesalahan yang ditemukan dalam penelitian ini adalah bentuk kesalahan morfologi dan sintaksis shiekibun pada mahasiswa pendidikan Bahasa Jepang Tahun Masuk 2017 Universitas Negeri Padang. Berdasarkan hasil penelitian, pada deskripsi data dapat dilihat bahwa bentuk kesalahan yang paling tinggi terjadi adalah bentuk kesalahan sintaksis dengan jumlah kesalahan sebanyak 432 dan persentase sebesar 59,8\%. Sebagaimana sutedi (2014:64) mengatakan bahwa kesalahan sintaksis merupakan cabang linguistik yang mengkaji tentang struktur kalimat dan unsur-unsur pembentukannya. Hal ini menyebabkan bentuk kesalahan sintaksis dalam shiekibun banyak terjadi karena mahasiswa belum memahami penggunaan shiekibun secara keseluruhan baik dalam aspek penggunaan partikel, penggunaan kata kerja dan menerjemahkan.

Nilai terendah yang diperoleh mahasiswa adalah 30. Untuk mahasiswa yang mendapat nilai terendah pada indikator ini disebabkan karena mahasiswa tersebut kurang pemahaman akan penggunaan partikel dengan baik.

Jenis kesalahan yang ditemukan dalam penelitian ini adalah jenis kesalahan lapses dan mistake shiekibun mahasiswa pendidikan bahasa Jepang tahun masuk 2017 Universitas Negeri Padang. Berdasarkan hasil penelitian, pada deskripsi data dapat dilihat bahwa jenis kesalahan yang paling tinggi terjadi adalah jenis kesalahan lapses dengan jumlah kesalahan sebanyak 389 dengan persentase 53,8\%. Sebagaimana corder (dalam putri, 2018:20) mengatakan bahwa kesalahan lapses adalah penyimpangan bentuk lahir karena beralihnya pusat perhatian topic pembicaraan secara sesaat. Kesalahan ini terjadi akibat ketidaksengajaan dan tidak disadari oleh penuturnya. Jenis kesalahan lapses dalam penggunaan shiekibun banyak terjadi karena bisa disebabkan oleh kelelahan tubuh atau terburu-buru dalam mengerjakan tes sehingga kesalahan dalam penulisan

Penyebab kesalahan yang terdapat dalam penelitian ini adalah penyebab kesalahan yang disebabkan oleh, faktor performansi, faktor kompetensi dan faktor generalisasi dalam tes bunpou mahasiswa tahun masuk 2017 Program Studi Pendidikan Bahasa Jepang Universitas Negeri Padang. Berdasarkan hasil penelitian, pada deskripsi data dapat dilihat bahwa penyebab kesalahan yang paling tinggi terjadi disebabkan oleh faktor kompetensi dengan jumlah kesalahan sebanyak 511 dan persentase sebesar $70,7 \%$

Faktor kompetensi adalah kesalahan berbahasa yang disebabkan karena kurangnya pemahaman atau pengetahuan mengenai aturan dalam berbahasa. Hal ini 
menyebabkan banyak terjadinya kesalahan karena mahasiswa masih belum memahami aturan struktur pembentukan kalimat shiekibun bahasa Jepang dengan baik yang dapat dikategorikan cukup sulit. Penggunaan partikel, menentukan verba dan menterjemahkan kalimat yang menjadi pelaku dan objek yang dikenai perbuatan sering membuat mahasiswa kebingungan dan menyebabkan terjadinya kesalahan

\section{KESIMPULAN}

Berdasarkan pada penelitian yang telah dilakukan tentang analisis kesalahan shiekibun pada mahasiswa pendidikan bahasa Jepang tahun masuk 2017 Universitas Negeri Padang, dapat ditarik kesimpulan bahwa ditemukannya bentuk kesalahan (morfologi dan sintaksis), jenis kesalahan (lapses dan mistake) dan penyebab kesalahan ( faktor performansi, faktor kompetensi dan faktor generalisasi) pada shiekibun. Diantara bentuk kesalahan morfologi dan sintaksis, kesalahan yang paling tinggi terjadi adalah bentuk kesalahan sintaksis Kesalahan ini terjadi karena mahasiswa tidak menguasai aturan tata bahasa shieki.

Selanjutnya diantara jenis kesalahan lapses dan mistake, kesalahan yang paling banyak terjadi adalah lapses, terjadi karena mahasiswa kurang berhati-hati dalam menulis jawaban, bisa disebabkan karena faktor kelelahan atau terburu-buru dalam menjawab soal tes.

Kemudian yang terakhir penyebab kesalahan, diantara tiga penyebab kesalahan, yang paling banyak terjadi dalam penelitian ini adalah faktor kompetensi. Besarnya penyebab kesalahan ini terjadi karena mahasiswa masih kurang memahami materi tentang penggunaan shiekibun, baik dalam indikator mengidentifikasi partikel, mengidentifikasi penggunaan verba, dan menerjemahkan shieki dari bahasa Indonesia ke bahasa Jepang, dan dari bahasa Jepang ke bahasa Indonesia.

\section{REFERENSI}

Dahidi, Ahmad dan Sudjianto. 2009. Pengantar Linguistik Bahasa Jepang. Jakarta : Oriental

Hidayah, Lailatur Nurul. 2015. "Analisis Kesalahan Penggunaan Ukemi, Shieki,dan Shieki Ukemi dalam Kalimat Bahasa Jepang”., Universitas Negeri Semarang (https://lib.unnes.ac.id/18557/), diakses pada 13 Januari 2019

Ivond Mangerongkonda, (2013) “Analisis Kesalahan Kata Kerja Kausatif (Shieki Doushi) dalam Kalimat Bahasa Jepang. Universitas Negeri Semarang (https://lib.unnes.ac.id/18557/), diakses pada 14 Januari 2019

Pateda, Jos Daniel. 1997. Linguistik Edukasional. Jakarta : Erlangga

Pieka.2012. Analisis Kesalahan Berbahasa. Artikel. http://piiekaa.blogspot.com, diaksespada 16 Maret 2019. 
Pranowo. 1996. Analisis Pengajaran Bahasa. Yogyakarta: Gadjah Mada University Press.

Pratiwi, Dahidi, dan Haristiani. 2016. Analisis kesalahan pelafalan huruf konsonan tsu dalam bahasa Jepang terhadap penutur bahasa Indonesia. JAPANEDU, vol.1 no.1.

Setiadi, Bambang. 2006. Metode Penelitian untuk Pengajaran Bahasa Asing Pendekatan Kuantitatif dan Kualitatif.Yogyakarta : Graha Ilmu

Sugiyono. 2012. Metode Penelitian Kuantitatif Kualitatif dan R\&D. Bandung: Alfabeta.

Sutedi, Dedi. 2003. Dasar-Dasar Linguistik Bahasa Jepang. Bandung : Humaniora Utama Press.

Sutedi, Dedi. 2009. Penelitian Pendidikan Bahasa Jepang. Bandung : Humaniora dan UPI Press.

Tarigan, Hendry Guntur. 1988. Pengajaran Pemerolehan Bahasa. Jakarta: Depertemen Pendidikan dan Kebudayaan Direktorat Jendral Pendidikan Tinggi Proyek Pengembangan Lembaga Pendidikan Tenaga Kependidikan. 